\title{
Optimization of conditions for vegetative propagation of Taxus baccata by shoot cuttings: Effects of IBA, growth stage and seasonal differences
}

\section{Saumitro Das ${ }^{*}$ and L.K. Jha ${ }^{2}$}

${ }^{1}$ Karimganj Forest Division (Territorial) Karimganj- 788712, Assam, India.

${ }^{2}$ Department of Environmental Studies, North-Eastern Hill University, Shillong-793022, Meghalaya, India.

Received: 1/19/2018; Accepted: 1/30/2018

\begin{abstract}
Taxus baccata is a highly valued medicinal tree, but overexploitation and inadequate natural regeneration, in addition to habitat destruction, has increased the threat of extinction. Various researchers have proposed shoot cuttings as cost effective method for propogation of this noble tree species because its regeneration through seed is very poor. The present study was conducted to investigate the effect of growth stage of shoots and IBA concentrations on rooting during four different seasons. Regardless of season, rooting was influenced by growth stage, IBA treatment and their interaction. Best rooting performance was exhibited by cuttings planted during rainy season. Cuttings of second year shoot scored the highest rooting percentage in all seasons $(47.3 \%$ in rainy $>26.9 \%$ in autumn $>10.2 \%$ in winter) except in spring where third year shoot's cutting $(22.8 \%)$ had the highest value. Rooting of cutting was enhanced by IBA treatment. Highest rooting percentage during spring $(22.9 \%)$ and rainy season $(44.0 \%)$ was achieved with low concentration of IBA (1000 ppm) whereas during autumn (25.9\%) and winter season (28.4\%) rooting was induced by high concentration of IBA (4000-5000 ppm). The interaction between growth stage and IBA treatment was significant for all season except winter.
\end{abstract}

Keywords: IBA, growth stage, rooting percentage, seasonal difference, shoot cuttings, Taxus baccata.

\section{Introduction}

Himalayan Yew, Taxus baccata L. (synonym Taxus baccata ssp. wallichiana (Zucc.) Pilg.) belongs to the family Taxaceae and is a long-lived, shade tolerant conifer. It occurs in patches in subtropical, temperate and alpine environments and distributed from Pakistan to Southwest China, Nepal and Bhutan, mainly at elevations of 1800 to $3300 \mathrm{~m}$ a. s. 1. (Lanker et al., 2010). In India, Taxus is found all along the Himalayas from Ladakh eastward to Khasi and Jaintia Hills, Naga Hills and Manipur between 2,300 and 3,400 $\mathrm{m}$ a. s. L. (Bhatnagar and Moitra, 1996). This species is primarily valued for 'paclitaxel' a mitotic inhibitor, extracted from its leaves and barks. This compound is used in the treatment of patients with lung, breast and ovarian cancer (Jaziri et al., 1996). As such, this valuable tree is being overexploited mostly by various collectors, traders and industrialists. The present rate of exploitation has rendered it endangered (Pant and Samant, 2008). Though a few good stocks of Taxus exist in Meghalaya, India the tree is facing threat due to degradation of its natural habitat. The effect of overutilization and habitat degradation are exacerbated by the species' poor natural regeneration process, its slow growth rate and long seed dormancy period of 1.5-2 years (Steinfield, 1992). Moreover the regeneration through seed is very difficult (Zarek, 2007) due to its precocious germination (Flores and Scrignoli, 1991; Rajewski et

\section{*Corresponding Author:}

Saumitro Das,

Assistant Conservator of Forest,

Karimganj Forest Division (Territorial),

Karimganj- 788712, Assam, India.

E-mail: suman.envt@gmail.com al., 2000). However few studies found that some Taxus species may be propagated using vegetative propagation (Schneck, 1996). For some species, vegetative propagation can be an important aspect for tree improvement and is useful for developing quick and economic methods for producing plant materials with certain desired characters (Libby, 1974). Of all methods of vegetative tree propagation, rooting of branch (shoot) cuttings is the most cost effective. Unlike other Taxus species, Taxus baccata is difficult to root and often requires more time to root (Fordham and Spraker, 1977). However rooting can be improved by controlling factors such as time of collection; cutting size; age of the source plant and cuttings; and root promoting treatments (Silva, 1985; Ragonezi et al., 2010). Rooting potential of most woody species depends on age of the cuttings as ageing of tissue is the major cause of declining the rooting ability (Husen and Pal, 2006). Maturation of cutting is mainly associated with (1) chronological ageing of individual branch segments and (2) distance to the basal parts of shoots (Hartmann et al., 2009).

Seasonal variation in rooting ability is due to changes in many plant and environmental factors including nutritional status, phenological stage, and climatic conditions. Many studies (Vieitz and Pena, 1968; Nanda and Anand, 1970; Arya and Hoque, 
1982; Uniyal et al., 1985; Cristofori et al., 2010) demonstrate that variation in rooting ability of stem cuttings of different tree species according to season. The magnitude of rooting, even in species that root throughout the year, varies considerably with season (Morshita, 1964). Although adventitious rooting of Taxus baccata stem cuttings using auxin (IBA) is used by some workers (Nandi et al., 1996 Mitter and Sharma, 1996; Khali and Sharma, 2003), most of the research has been restricted to the temperate regions of India. Currently limited information is available on seasonal variation of rooting in Taxus baccata shoots. Hence the present investigation was carried out to examine seasonal variation in the rooting performance of shoot cuttings for the propagation of Taxus baccata in relation to the growth stage of shoots and IBA treatment.

\section{Material and Methods}

\section{Study area}

The study was carried out in the experimental garden of Department of Environmental Studies, North-Eastern Hill University, located at Shillong in Meghalaya, India (9153' E; 2536' $\mathrm{N}$ and $1426 \mathrm{~m}$ asl at altitude). The study period was between 2014 and 2015 covering the spring (March and April), rainy (May to August), autumn (September to November) and winter season (December to February). The vegetation type of the area is predominantly subtropical with annual average rainfall of $2200 \mathrm{~mm} .70-80 \%$ of annual rainfall was received during rainy season and lowest rainfall $(<5 \%)$ was received during the winter. The relative humidity is always more than $50 \%$ which exceeds above $80 \%$ during the rainy season. The average annual temperature during study period ranges between a maximum of $30.8^{\circ} \mathrm{C}$ to a minimum of $6.4^{\circ} \mathrm{C}$. The mean monthly weather data is summarized in the Figure 1.

The shoots were collected from the phenotypically superior trees of Taxus baccata growing in the premises of the Botanical Survey of India, Eastern Circle in Shillong. Collection was made for four seasons: Spring (first week of March), Rainy (second week of May), Autumn (first week of September) and Winter (first week of December). The branch bearing at least 10 internodes were excised at point of its origin from the main shoot. The cuttings were then stored in moist polythene bags in order to prevent desiccation during transportation. The final cuttings were $15-20 \mathrm{~cm}$ long and maximum of $1 \mathrm{~cm}$ diameter were clipped from given branches. The needles were removed up to $2 \mathrm{~cm}$ above the basal portion of cuttings and grouped according to growth stage of shoot i.e. first year, second year and third year shoot. Current year shoots are avoided due to its delicate nature and prone to desiccation.

\section{Preparation of IBA solution and Planting}

IBA solutions ranging from 0 to $5000 \mathrm{ppm}$ were prepared by dissolving required amount of IBA in $0.1 \mathrm{~N} \mathrm{NaOH}$ and the desired concentration was obtained by adding distilled water. The quick dip method of IBA application (Hartmann et al., 2009) was used throughout the experiment. After chemical treatment, basal end of each cutting was dried for 15 minutes and then all cuttings were planted vertically in perforated poly-pots $(18 \mathrm{~cm}$ deep and $6.5 \mathrm{~cm}$ diameter containing equal parts of soil, sand and FYM). Finally all potted cuttings were brought under polyhouse and allotted according to the experimental design. The cuttings were watered regularly as when depending on weather condition and moisture status of rooting medium.

\section{Experimental design}

For each season, the experimental design was a randomised block design with a factorial arrangement of treatments (3 types of cutting $\mathrm{x} 6$ IBA concentrations). There were three blocks (replications) and 10 cuttings per treatment per block.

\section{Rooting observation and data analysis}

The cuttings planted were harvested after 5 months and data were recorded on rooting percentage (number of cutting rooted). Only those cuttings with one or more clearly visible root initials of $\geq 1 \mathrm{~mm}$ long were considered as rooted and used for calculating percent rooting.

Data analyses were performed by using Statistical Package for Social Sciences (SPSS) version 16. Following Hoshmand (1994), the data recorded were subjected to analysis of variance and regression analysis (ANOVA). Least significant different (LSD) at $5 \%$ probability was used to compare significantly different means of different treatments. The data of rooting percentage was transformed by arc sine transformation to meet the normality of assumption for analysis of variance (Hoshmand 1994). Levene's test of homogeneity of variance among four seasons for each parameter was conducted and it was found significant ( $p \leq$ 0.05). It implies that there was no homogeneity among error variances. Thus, the data were studied and statistically analysed separately and have been presented accordingly in the results.

\section{Results}

The regeneration success of Taxus baccata shoot cuttings was greatly influenced by seasonal difference, growth stage and IBA treatment. Overall, rainy season's cuttings displayed better rooting performance followed by spring and autumn season (Table 1). The variable rooting response of shoot cuttings of Taxus baccata throughout the four seasons indicates that the effect of growth stage and the IBA treatment varies with 
season. Only second and third year cuttings were taken into consideration for winter season, because all the first year cuttings planted in same season dried off within one month.

ANOVA revealed that the growth stage had significantly $(\phi<0.05)$ influenced the rooting of Taxus baccata shoot cuttings in all seasons except in winter (Table 2). In spring season, maximum rooting $(22.8 \%)$ took place in cuttings of third year old shoot, whereas in the rest of the seasons, second year old shoot's cuttings exhibited highest rooting success $(47.3 \%$ in rainy; $26.9 \%$ in autumn; $10.2 \%$ in winter) (Table 3 ). Poor rooting recorded in winter season as only few second $(10.2 \%)$ and third year $(8.5 \%)$ shoot cuttings able to root (Table 3).

Data analysis showed that the various concentration of IBA responded differently in different seasons. According to ANOVA, IBA treatment had significant effect $(\phi<0.05)$ on rooting of Taxus baccata cutting in rainy, autumn and winter season (Table 2). In rainy season, maximum rooting was induced by $1000 \mathrm{ppm}$ (44.0\%) followed by 2000 ppm (36.7\%) (Table 3). Minimum rooting was recorded in $5000 \mathrm{ppm}$ of IBA concentration $(24.7 \%)$. In contrast, higher concentration of IBA improved rooting in autumn and winter. $5000 \mathrm{ppm}$ IBA $(25.9 \%)$ and 4000 ppm IBA $(23.2 \%)$ induced more rooting in autumn seasons (Table 3 ). Similarly in winter season, $4000 \mathrm{ppm}(28.4 \%)$ IBA had highest rooting percentage followed by $5000 \mathrm{ppm}$ IBA $(20.7 \%)$. In both autumn and winter seasons, low rooting percentage of cuttings was recorded in IBA concentration less than 3000 ppm (Table 3).

In interaction, the combined effect of growth stage and IBA treatment was found to be significant $(p<$ 0.05 ) in all seasons except winter (Table 2). IBA response to first year and second year growth stage during spring and rainy season showed slightly negative linear trend where rooting percentage decreased as concentration of IBA increased (Table 4). It had been also observed that untreated cuttings of both spring and rainy seasons displayed moderate rooting success (Table 4). 5000 ppm IBA treated cutting of first year shoot; and 4000 and 5000 ppm IBA treated cuttings of second year old shoot failed to root during spring season (Table 4). However cutting collected during autumn and winter season exhibited reverse rooting pattern than that of spring and rainy season. The second year shoot exhibited positive linear relationship with increasing level of IBA concentration during autumn and winter season (Table V). In winter season, rooting of second and third year cutting took place only with IBA concentration greater than 2000 ppm. Interestingly, it had been observed that irrespective of season, the rooting percentage of third year shoot's cuttings also linearly increased with increasing level of IBA concentration (Table
4). The higher rooting success of third year shoot's cuttings was achieved with IBA concentration more than $3000 \mathrm{ppm}$.

\section{Discussion}

From the experiment it was found that there are two alternating phases of rooting of cuttings during the annual growth cycle of Taxus baccata. The profuse rooting of cuttings occurred in spring and rainy season whereas light rooting was observed during autumn and winter. Overall, maximum rooting response of Taxus baccata shoot cuttings was exhibited in the rainy, moderate rooting during the spring and autumn, and minimum rooting during in winter. In the temperate region spring season is considered ideal for cutting propagation of Taxus wallichiana (Kaul, 2008). This season has favourable day temperatures of $21-29^{\circ} \mathrm{C}$ combined with night temperatures of $14-20^{\circ} \mathrm{C}$. In the sub-tropical region of Meghalaya with an elevation ranging from (14001500 m.a.s.l), the required temperature condition was observed only during the rainy where average day and night temperatures were $28.7^{\circ} \mathrm{C}$ and $19.1^{\circ} \mathrm{C}$, respectively (Figure 1). It was also found that the relative humidity and rainfall of the region play a significant role. Low relative humidity $(<60 \%)$ during the spring and low rainfall during the autumn caused desiccation stress which might result in low rooting. Scarce and delayed rooting during winter might be due to a time when the axillary buds are in a dormant stage and activity of cambial cell is low. But by using cuttings from the proper growth stage, rooting at any particular season can be improved. It is also worth mentioning that endogenous growth hormones are important aspect of adventitious root formation since the seasonal changes in the effectiveness of exogenously supplied auxin varies with season (Nanda and Anand 1970).

Seasonal rooting response of Taxus baccata is also governed by the nature of stem cuttings. In all seasons except spring, maximum rooting was exhibited by second year shoots [Figure 2 (b \& d)]. In the present study, the least case of rooting success was reported in cutting from first year shoots. Our results is similar to the finding of Kaul (2008) where the highest rooting response was exhibited by second year cuttings and lowest with third year cuttings. Anatomically, second year shoots are green but not soft or flaccid as the first year shoots and rigid but not as hard as the third year shoots. Thus the second year shoots can withstand biotic stress longer than the first year shoots and they produce root easier than the third year shoots. Though having greater rooting potential (due to its apical position where most of endogenous auxins are synthesized), newly grown shoots of first year shoot cuttings showed poor rooting success. Most of the cuttings died within one month of planting. The high mortality rate of 
the first year cuttings was due to its flaccid nature as most of them had undergone wilting [Figure 2 (a)]. Therefore their propagation requires high maintenance costs such as specialised polyhouse and tedious water management such as mist and fog system. The third year cuttings had better rooting success than first year due to its hard lignified outer covering which protect them from rapid desiccation and pest or fungal decay. But its rooting capacity is lower [Figure 2 (c)] than with second year cuttings. This might be attributed to poor physiological status (nutrients, carbohydrates, water, etc) of shoots (Mitchell et al., 2004), lower level of endogenous root promoter, increased lignifications and accumulation of inhibitory substances such as phenolics (Dirr and Heuser, 1987; Hartmann et al., 2009). On the other hand, semi hard nature, higher tissue sensitivity and greater meristematic activity of second year shoots made it superior than other types of shoots in term of rooting ability.

Table 1. Effect of season on rooting percentage Taxus baccata shoot cuttings

\begin{tabular}{cc}
\hline Season & Rooting percentage \\
\hline Spring & $17.5^{\mathrm{b}}$ \\
Rainy & $32.1^{\mathrm{a}}$ \\
Autumn & $15.2^{\mathrm{b}}$ \\
Winter & $6.9^{\mathrm{c}}$ \\
LSD & $6.2^{\mathrm{C}}$
\end{tabular}

Means with the same letter (superscript) in each column are not significantly different.

Table 2. ANOVA mean sum of the square and $p$ value for sprouting and rooting percentage, root number and root length of Taxus baccata shoot cuttings of four seasons

\begin{tabular}{lccccc}
\hline Rooting percentage & & Spring & Rainy & Autumn & Winter Z \\
\hline Source of Variation & df & p-value & p-value & p-value & p-value \\
Growth Stage (G) & 2 & 0.01 & 0.00 & 0.00 & 0.48 ss \\
IBA Treatment (I) & 5 & 0.22 ss & 0.00 & 0.00 & 0.00 \\
G X I & 10 & 0.00 & 0.00 & 0.01 & 0.83 ns \\
Error & 36 & & & & \\
\hline
\end{tabular}

Z For winter season, degree of freedom (df) was taken as 1, 5, 5 and 24 for growth stage, IBA treatment, G $\mathrm{X} \mathrm{I}$ and Error respectively; $n s$ not significant at $p \leq 0.05$.

Table 3. Mean effect of growth stage and IBA treatment rooting percentage,

\begin{tabular}{|c|c|c|c|c|}
\hline Variables & Spring & Rainy & Autumn & Winter \\
\hline \multicolumn{5}{|l|}{ Growth Stage } \\
\hline First year & $15.6^{\mathrm{b}}$ & $20.7^{c}$ & $3.6^{c}$ & - \\
\hline Second year & $13.4^{\mathrm{b}}$ & $47.3^{\mathrm{a}}$ & $26.9^{a}$ & $10.2^{a}$ \\
\hline Third year & $22.8^{\mathrm{a}}$ & $28.4^{b}$ & $13.9^{\mathrm{b}}$ & $8.5^{\mathrm{a}}$ \\
\hline LSD at $5 \%$ & 5.7 & 7.2 & 7.0 & 5.8 \\
\hline IBA Treatment & Spring & Rainy & Autumn & Winter \\
\hline $0 \mathrm{ppm}$ & $17.5 \mathrm{ab}$ & $28.5 \mathrm{bc}$ & $8.4^{\mathrm{c}}$ & $0.0^{\mathrm{b}}$ \\
\hline $1000 \mathrm{ppm}$ & $22.9^{a}$ & $44.0^{\mathrm{a}}$ & $12.5^{\mathrm{c}}$ & $0.0^{\mathrm{b}}$ \\
\hline $2000 \mathrm{ppm}$ & $19.0 \mathrm{ab}$ & $36.7 \mathrm{ab}$ & $6.2^{c}$ & $0.0^{\mathrm{b}}$ \\
\hline $3000 \mathrm{ppm}$ & $12.6^{\mathrm{b}}$ & $32.9 \mathrm{bc}$ & $13.5 \mathrm{bc}$ & $6.8^{b}$ \\
\hline $4000 \mathrm{ppm}$ & $16.6 \mathrm{ab}$ & $26.1 \mathrm{bc}$ & $23.2 \mathrm{ab}$ & $28.4^{a}$ \\
\hline $5000 \mathrm{ppm}$ & $15.0 \mathrm{ab}$ & $24.7^{c}$ & $25.9^{a}$ & $20.7^{a}$ \\
\hline LSD at $5 \%$ & 8.0 & 10.2 & 9.8 & 8.2 \\
\hline
\end{tabular}

Means with the same letter (superscript) in each column are not significantly different.

Table 4. Interactive effect of IBA treatment on rooting percentage of 3 different growth stages of Taxus baccata shoot cuttings

\begin{tabular}{|c|c|c|c|c|c|c|c|}
\hline Spring & \multicolumn{3}{|c|}{ Growth Stage } & Rainy & \multicolumn{3}{|c|}{ Growth Stage } \\
\hline IBA Treatment & First year & Second year & Third year & IBA Treatment & First year & Second year & Third year \\
\hline 0 ppm & $28.8^{a}$ & $23.9^{a}$ & $0.0^{\mathrm{c}}$ & $0 \mathrm{ppm}$ & $33.0^{\mathrm{a}}$ & $43.1 \mathrm{~cd}$ & $9.5 \mathrm{~b}$ \\
\hline $1000 \mathrm{ppm}$ & $33.0^{\mathrm{a}}$ & $28.8^{a}$ & $6.8 \mathrm{bc}$ & $1000 \mathrm{ppm}$ & $39.1^{\text {a }}$ & $81.1^{\mathrm{a}}$ & $11.7^{b}$ \\
\hline $2000 \mathrm{ppm}$ & $12.6^{\mathrm{b}}$ & $21.1^{\mathrm{a}}$ & $23.4^{\mathrm{ab}}$ & $2000 \mathrm{ppm}$ & $26.1^{\mathrm{ab}}$ & $59.8^{b}$ & $24.2^{\mathrm{ab}}$ \\
\hline $3000 \mathrm{ppm}$ & $6.8^{b}$ & $6.8^{b}$ & $24.2 \mathrm{ab}$ & $3000 \mathrm{ppm}$ & $12.6 \mathrm{bc}$ & $45.0 \mathrm{bc}$ & $41.1^{a}$ \\
\hline $4000 \mathrm{ppm}$ & $12.6^{\mathrm{b}}$ & $0.0^{\mathrm{b}}$ & $37.2^{a}$ & $4000 \mathrm{ppm}$ & $6.8^{c}$ & $26.6^{\mathrm{e}}$ & $45.0^{\mathrm{a}}$ \\
\hline $5000 \mathrm{ppm}$ & $0.0^{\mathrm{b}}$ & $0.0^{\mathrm{b}}$ & $45.1^{a}$ & $5000 \mathrm{ppm}$ & $6.8^{c}$ & 28.3 de & $39.1^{\text {a }}$ \\
\hline LSD & 13.8 & 9.2 & 20.3 & LSD & 15.1 & 15.8 & 24.8 \\
\hline Autumn & \multicolumn{3}{|c|}{ Growth Stage } & Winter & \multicolumn{2}{|c|}{ Growth Stage } & \\
\hline IBA Treatment & First year & Second year & Third year & IBA Treatment & First year & Second year & Third year \\
\hline $0 \mathrm{ppm}$ & $6.8 \mathrm{ab}$ & $18.4^{\mathrm{c}}$ & $0.0^{\mathrm{b}}$ & $0 \mathrm{ppm}$ & - & $0.0^{\mathrm{c}}$ & $0.0^{\mathrm{c}}$ \\
\hline $1000 \mathrm{ppm}$ & $18.0^{\mathrm{a}}$ & $12.6^{c}$ & $6.8 \mathrm{ab}$ & $1000 \mathrm{ppm}$ & - & $0.0^{\mathrm{c}}$ & $0.0^{\mathrm{c}}$ \\
\hline $2000 \mathrm{ppm}$ & $0.0^{\mathrm{b}}$ & $11.7^{\mathrm{c}}$ & $6.8 \mathrm{ab}$ & $2000 \mathrm{ppm}$ & - & $0.0^{\mathrm{c}}$ & $0.0^{\mathrm{c}}$ \\
\hline $3000 \mathrm{ppm}$ & $0.0^{\mathrm{b}}$ & 28.8 bc & $11.7 \mathrm{ab}$ & $3000 \mathrm{ppm}$ & - & $6.8^{c}$ & $6.8 \mathrm{bc}$ \\
\hline $4000 \mathrm{ppm}$ & $0.0^{\mathrm{b}}$ & $43.1 \mathrm{ab}$ & $26.4 \mathrm{ab}$ & $4000 \mathrm{ppm}$ & - & $33.0^{\text {a }}$ & $23.9^{\mathrm{a}}$ \\
\hline $5000 \mathrm{ppm}$ & $0.0^{\mathrm{b}}$ & $46.9^{a}$ & $30.8^{a}$ & $5000 \mathrm{ppm}$ & - & $21.1^{b}$ & $20.3^{\mathrm{ab}}$ \\
\hline LSD & 13.0 & 16.5 & 24.3 & LSD & - & 1.1 & 14.8 \\
\hline
\end{tabular}

Means with the same letter in each category are not significantly different. 


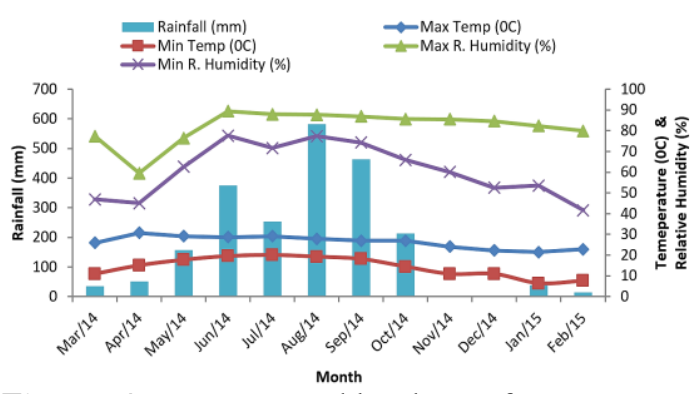

Figure 1. Mean monthly data of temperature, rainfall and relative humidity of the experimental site.

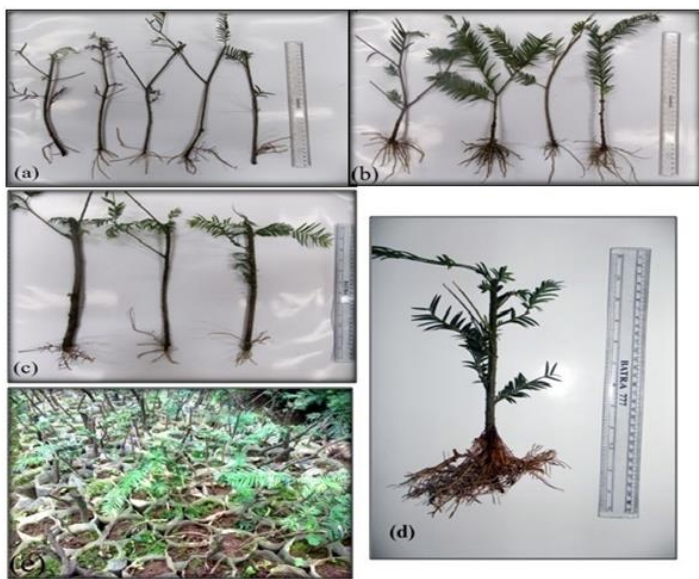

Figure 2. Taxus baccata cuttings (a) Rooted cuttings of first year shoots during rainy season (b) Rooted cuttings of second year shoots during rainy season (c) Rooted cuttings of third year shoots during rainy season (d) A well rooted 16 months old, second year shoot (e) Rooted plants transplanted in open condition for acclimatization

The effect of IBA treatment on rooting of Taxus baccata cuttings varied with season. Lower concentrations of IBA (0-1000 ppm) effectively induced rooting of cutting during spring and rainy seasons, whereas rooting of cuttings in autumn and winter only took place when treated with higher concentrations ( $\geq 3000 \mathrm{ppm})$. So it can be said that that an annual rhythmic change in rooting response of Taxus baccata stem cuttings existed. Generally plants are active during the spring and rainy seasons and the level of endogenous auxin was supposed to be high due to its meristematic activity. During these seasons, optimally low doses of IBA can induce profuse rooting in cutting. On the other hand, higher concentrations of exogenous auxin (IBA) proved to be detrimental rather than beneficial because the entire auxin concentration is raised to supra optimal level. After rainy, application of higher doses of (IBA more than $3000 \mathrm{ppm}$ ) proved helpful for root initiation in cuttings. The inhibitory effect of higher concentration on rooting however could have decreased gradually with decreasing temperature, causing a slowdown in the meristematic activity, so that application of exogenously applied auxins might raise concentration to optimal level, causing intense rooting as compared to lower IBA concentrations. This effect may either be due to increase in the concentration of auxin to optimal level or to the fact that these exogenously supplied auxin were more effective in mobilization of reserved food materials. However rooting of third year shoots increased linearly with increasing concentrations of IBA throughout the year. This suggests that tissues of older shoots are sensitive only to higher concentration of IBA.

\section{Conclusion}

The propagation of Taxus baccata through shoot cuttings is possible throughout the year. However to reduce the economical loss, in term of planting materials and maintenance cost, selection of shoot of proper growth stage is essential. Second year shoots are optimum for cutting propagation of Taxus baccata. For the propagation of first year shoots, extra care should be taken such as covering them with poly-sheet and regular watering, especially in spring when atmosphere is very dry. The rooting performance of shoot cuttings can be enhanced by exogenous IBA application. It is also necessary to consider tissue sensitivity in relation to plant growth regulators since older cuttings (three year old shoot) require higher concentration of IBA $(\leq 3000 \mathrm{ppm})$ as compared to younger ones. IBA requirement for root formation in cuttings also affected by season. In active growing seasons (spring and rainy) it is advisable to use optimally low concentration of IBA $(\leq 2000 \mathrm{ppm})$. Thus from the present study, it is concluded that the rainy season is the best for the propagation of Taxus baccata (in the sub-tropical region of Meghalaya with an elevation ranging from (1400-1500 m.a.s.l, temperature between $19^{\circ} \mathrm{C}$ and $\left.29^{\circ} \mathrm{C}\right)$

\section{Acknowledgement}

The authors are thankful to Dr. A. A. Mao, Scientist E \& in charge, Botanical Survey of India, ERC, Shillong, Meghalaya for providing planting materials for research work. The authors also thank Dr. Petevino Chase for her helpful suggestions during the research work. The financial assistance to Saumitro Das in the form of UGC NET fellowship from University Grants Commission (UGC), New Delhi, is gratefully acknowledged.

\section{References}

1. Arya R.S. and M.S. Haque. Air layering in Pinus patula Schl. and Cham. and Pinus caribaea Morelet. Var. Hondurensis. Indian Forester 108.1 (1982) pp. 66.

2. Bhatnagar S.P. and A Moitra. Gymnosperms. New Age International Ltd. New Delbi (1996) pp. 310.

3. Cristofori V, Y Rouphael and E Rugini. Collection time, cutting age, IBA and putrescine effects on root formation in Corylus avellana L. cuttings. Scientia Horticulturae 124 (2010) pp. 189-194. 
4. Dirr M.A. and C.W. Heuser. The reference manual of woody plant propagation: from seed to tissue culture. Varsity press Inc. Georgia (1987) pp. 23.

5. Flores H.E. and P.J. Scrignoli. In vitro culture precocious germination of Taxus embryos. In Vitro Cellular and Developmental Biology-Plant 27 (1991) pp. 139-142.

6. Fordham A.J. and L.S. Spraker. Propagation manual of selected gymnosperms. Arnoldia, 37 (1977) pp. 1 88 .

7. Hartmann H.T., D.E. Kester, R.L. Geneve and F.T. Davies. Plant propagation principle and practices. Prentice-Hall Inc. New Delhi (2009) pp. 377-410.

8. Hoshmand A.R. Experimental Research Design and Analysis. CRC Press Inc. United State of America (1994).

9. Husen A and M Pal. Variation in shoot anatomy and rooting behaviour of stem cutting in relation to age of donor plants in teak (Tectona grandis Linn. F). New Forests (31) 2006, 57-73.

10. Jaziri M, A Zhiri, Y.W. Guo, J.P. Dupont and K Shimomura. Taxus sp. Cell tissue and organ culture as alternatives sources of taxoid production: A literature survey. Plant Cell Tissue and Organ Culture 46 (1996) pp. 59-75.

11. Kaul K. Variation in rooting behaviour of stem cuttings in relation to their origin in Taxus wallichiana Zucc. New Forest, 36 (2008) 217-224.

12. Khali R.P. and A.K. Sharma. Effect of phytohormones on propagation of Himalayan Yew (Taxus Baccata L.) through stem cuttings. Indian Forester 129 (2003) pp. 289-294.

13. Lanker U, A.R. Malik, N.K. Gupta and J.S. Butola. Natural regeneration status of the endangered medicinal plant Taxus baccata Hook.F. Syn. T. Wallichiana, in northwest Himalaya. International Journal of Biodiversity Science, Ecosystem Services \& Management, 6.1-2 (2010) pp. 20-27.

14. Libby W.J. The use of vegetative propagules in forest genetic and tree improvement. New Zealand Journal of Forestry Science 4 (1974) pp. 440-447.

15. Mitchell R.G., J Zwolinski and N.B. Jones. A review on the effects of donor maturation on rooting and field performance on conifer cuttings. South African Forestry Journal 201 (2004) 53-63.

16. Mitter $\mathrm{H}$ and A Sharma. Propagation of Taxus baccata Linn. by stem cutting. Indian Forester 125.2 (1999) pp. 289-294.

17. Morshita Y. Root disease of tree cuttings and their control. Bull for Experimental Station, Merguro. Tokyo 165 (1964) 293.
18. Nanda K.K. and V.K. Anand. Seasonal changes in auxin effect on rooting of stem cuttings of Populus nigra on its relationship with mobilization of starch. Physiologia Plantarum 23 (1970) pp. 99.

19. Nandi S, L.M.S. Palni, and H.C. Rikhari. Chemical induction of adventitious root formation in Taxus baccata cuttings. Plant Growth Regulation 19 (1996) pp. 117- 122.

20. Pant S and S Samant. Population Ecology of the Endangered Himalayan Yew in Khokan Wildlife Sanctuary of North Western Himalaya. Journal of Mountain Science 5 (2008) pp. 257-264.

21. Ragonezi C, K Klimaszewska, R.M. Castro, M Lima, $P$ de Oliveira and M.A. Zavattieri. Adventitious rooting of conifers: influence of physical and chemical factors (Review). Tree 24 (2010) pp. 975 992.

22. Rajewski M, S Lange and H.H. Hattemer. Problems of reproduction in the genetic conservation of rare tree species: the example of common yew (Taxus baccata L.). Forest Snow Landscape Research, 75 (2000) pp. 251-266.

23. Schneck V. Studies on influence of clone on rooting ability and rooting quality in the propagation of cuttings from 40- to 350-year-old Taxus baccata L. ortets. Silvae Genetica 45 (1996) pp. 246-249.

24. Silva A.A. Vegetative propagation of Pinus spp. Silvicultura 2 (1985) pp.141.

25. Steinfield D. Early lessons from propagating Pacific yew. Rocky Mountain Forest and Range Experiment Station Technical Research Report (1992) pp. 221

26. Uniyal D.P., R.C. Thapliyal and M.S. Rawat. Vegetative propagation of Sandal by root cuttings. Indian Forester 111.3 (1985) pp.145-148.

27. Vieitz E and J Pena. Seasonal rhythm of rooting of Salix atrocinera cuttings. Physiologia Plantarum 21 (1968) pp. 544.

28. Zarek M. A practical method for overcoming the dormancy of Taxus baccata isolated embryos under in vitro conditions. In Vitro Cellular and Developmental Biology-Plant, 43 (2007) pp.623-630.

\section{Cite this article as:}

Saumitro Das and L.K. Jha. Optimization of conditions for vegetative propagation of Taxus baccata by shoot cuttings: Effects of IBA, growth stage and seasonal differences. Annals of Plant Sciences 7.2 (2018) pp. 2082-2087.

http://dx.doi.org/10.21746/aps.2018.7.2.18

Source of support: University Grants Commission (UGC), New Delhi

Conflict of interest: Nil 